\title{
European Crisis and the Effect on Albanian Economy
}

\section{Güngör Turan}

\author{
Ph.D, Department of Economics, Epoka University, Tirana, Albania, \\ gturan@epoka.edu.al
}

\section{Arlind Bala}

Master Student at Banking and Finance Department, Epoka University, Tirana, Albania,

Doi:10.5901/ajis.2014.v3n3p230

arlindbala@live.com

\begin{abstract}
This article will analyze how did the financial and banking crisis of EU countries affected Albania in different aspects. The aim of the study is to give a comprehensive overview of the impact of the EU crisis in Albania considering different inter-related elements. The methodology used for measuring the impact will be based on macroeconomic indicators and all the available official data and statistics were sourced from central and local institutions in Albania and EU. Firstly will be given a brief history of the immigrations of Albanians in different European countries and analyzed their importance in Albanian economy whether via remittances or investments in some cases. Lastly to the most crucial point, after having done a regression analysis, we will get a more precise figure about the impact of EU in Albania (where mostly it is connected to countries like Italy and Greece)
\end{abstract}

Keywords: Real GDP growth, Unemployment, Inflation, Real interest rate, Remittances, exchange rate, bad credits, etc

\section{Introduction}

The objective of this study is how the financial and economical crisis in European union affected the overall economy in Albania. Starting as a financial sector crisis and soon extending to a global scale, the world financial crisis has assumed the features of a deep, all-encompassing economic crisis. It is clear that the financial figures show a stiff decline on the Albania's performance, resulting in high unemployment, high informal market, un stable inflation and critical levels of remittances. It is important to mention that the remittances played a crucial role in the history of Albania feeding many domestic families and businesses, accompanied by big names if Bank Industry such as NBG, Emporiki Bank, Intesa San Paolo (Italian ownership) and many others which come from states with the highest level immigrants and abroad incomes.

The crisis showed none the less that new regulations must be written and approved, markets should be more supervised. The governments should regulate and direct different sectors of economy. In Albania, sectors like production, construction and services felt a high need of liquidity, as a result many of them declared bankruptcy.

On the political side, the true situation of Albania was faded and protected from governments implying that the European crisis is not and will not affect the domestic economy. It must be said that till 2009, even from international institutions like World Bank, our economy was immune and gave the idea of a stable and strong economy, neglecting the fact of the increasing at high leaps of public debt and stocks, which showed afterward the short terms decisions were not enough. In the next years, Albania was influenced as all the Balkan states from the crisis into shrinking of foreign investments and unstable macroeconomic policies. Experts tend to say that this late result was due to having small economies and stable banking system.

\section{Literature Review}

In order to explore how the EU debt crises would translate into an economy like Albania, we have looked into a few relevant studies. Our focus is to explain the growth prospect and debt crises of an economy and how it impacts on other economies because of ex- posed global linkages.

Calvo (1998) explained that countries that join a monetary union lose more than one instrument of economic policy such as their capacity to issue debt in a currency. Thus member countries of a monetary union become vulnerable because of the liquidity flows triggered by changing market sentiments which ultimately connects to solvency crises. Eichengreen et al. (2005) further explained that the liquidity crisis raises the interest rate which in turn leads to a solvency 
crisis which is not unique for members of a monetary union. There are further important implications of the increased vulnerability of member-countries of a monetary union. De Grauwe (2011) and Wolf (2011) illustrated that countries in a monetary union can be forced into a bad equilibrium, characterized by deflation, high interest rates, high budget deficits and a banking crisis as because members of a monetary union loose much of their capacity to apply counter-cyclical budgetary policies. Danieal et al. (2010) studied fiscal consolidation in M. M. SHIRAJ ET AL. 522 advanced economies over the past 30 years by using simple statistical techniques to investigate the short-term growth effects of consolidation and how those effects are influenced by such factors as monetary policy, international trade, the form of the consolidation and perceived sovereign risk. Their studies found that, fiscal consolidation typically has a contractionary effect on output. Generally the central banks offset some of these pressures by cutting policy interest rates. However the longer-term rates also typically decline, resulting in the impact on consumption and investment. In addition net exports spur due to nominal depreciation or currency devaluation.

Bianca et al. (2006) assessed the size and types of costs associated with sovereign default of the emerging market economies witnessed over the past 30 years. Their findings stated that sovereign defaults have the biggest impact on domestic output when they are combined with widespread failure of the domestic banking system and particularly when there is a triple (sovereign, banking and currency) crisis. And in some cases, such as following the Latin American crisis in the early 1980s and the more recent Russian crisis, sovereign defaults have precipitated broader instability in the global financial system. Dooley (2000) showed that default is often associated with a decline in output growth that is assumed to be due to domestic residents being unable to borrow from domestic as well as foreign creditors in the aftermath of crises. Caprio and Klingebiel (2003) explained that sovereign crises have usually materialized in recessions, when government and/or external debt has been large generally over 60\% of GDP and the fiscal balance in deficit (of over $2 \%$ of GDP). Although annual inflation was rapid in some cases, for example over $50 \%$ in Indonesia and Ecuador, it was negative or low in others, such as Argentina and Uruguay. He further noted that nearly all recent debt crises have been associated with a banking and/or currency crisis. Evidence from literature shows that, a crisis usually effects a externally driven economy through the various transmission channels of exports, imports, remittances, aid, foreign direct investment (FDI) flows, employment i.e. labor market, domestic resource mobilization, gross domestic product (GDP) growth and ultimately poverty. Eaton et al. (2008) found that shocks to manufacturing demand, particularly for durables, account for the bulk of the decline in trade/GDP across countries. Karshenas (2009) noted that the impact of the global economic crisis on different LDCs has varied depending on the nature of their trade specialization. He stated that the global economic crisis has led to a sharp reduction in world trade and rapid de-cline in commodity prices and it is one of the main mechanisms through which LDCs have been affected. Be-sides, decline in FDI has affected LDCs, particularly the oil and mineral exporting ones and remittance inflow.

\section{Data and Methodology}

In order to examine the relation between nominal interest rate and inflation rate in Albania needs not only the theoretical concepts, but also need a practical and econometric study as well. This study employs quarterly data from 1997 to 2013 so for a 17 year period. The data for this research are obtained from Central Bank of Albania (BoA).

The regression model in this study is:

$\mathrm{GDP}=\mathrm{a}+\beta_{1} \mathrm{FDI}++\beta_{2} \cdot \mathrm{INF}+\beta_{3} \mathrm{RMT}+\mathrm{e}$

Where: $\alpha$ : is the intercept

$\beta_{1} \beta_{2} \beta_{3}$ Is the estimated regression coefficients

$\mathrm{e}$ is the error term

GDP: Gross Domestic Product is the dependent variable

INF: Inflation rate is the independent variable

FDI: Foreign Direct Investments

RMT: Remittances

The hypothesis for this equation is represented by the following:

HO: Inflation rates, foreign direct investments and remittances have a significant impact on Gross Domestic Product in the long run

$\mathrm{H} 1$ : $\mathrm{HO}$ is not true 


\section{GDP and FDI Graph}

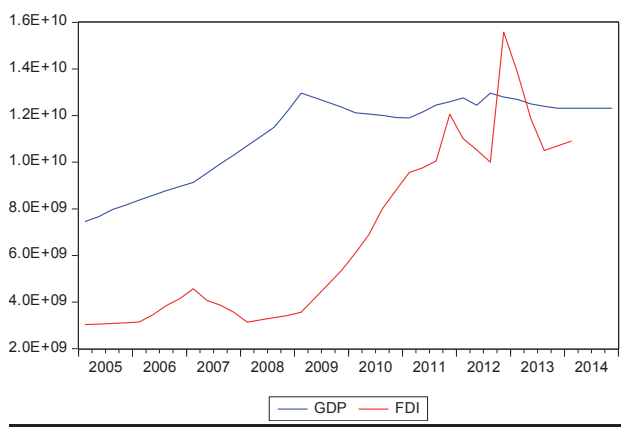

Abive is the graph of Gdp and Fdi which can be observed that they have affect each other. Datas are taken since 2005 till 2014. Note: FDI has a strong decrease in 2013

\section{Export Graph}

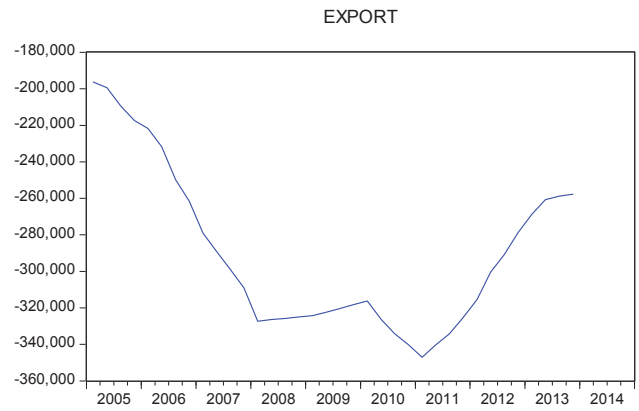

\section{FDI Graph}

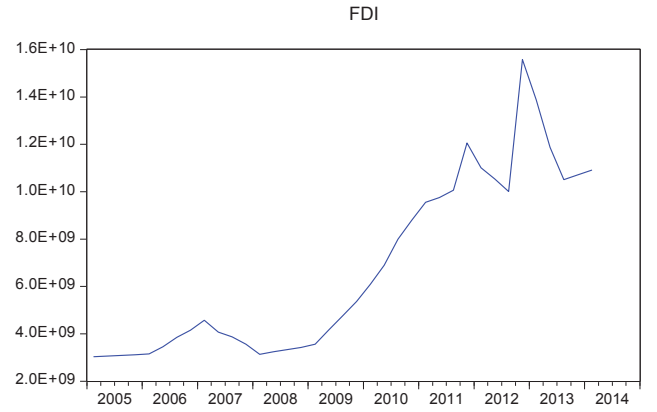




\section{Remittances Graph}

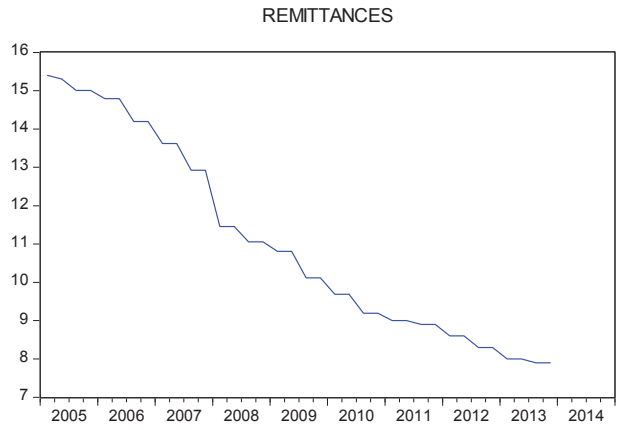

\section{GDP \& Exports (Scatter Graph)}

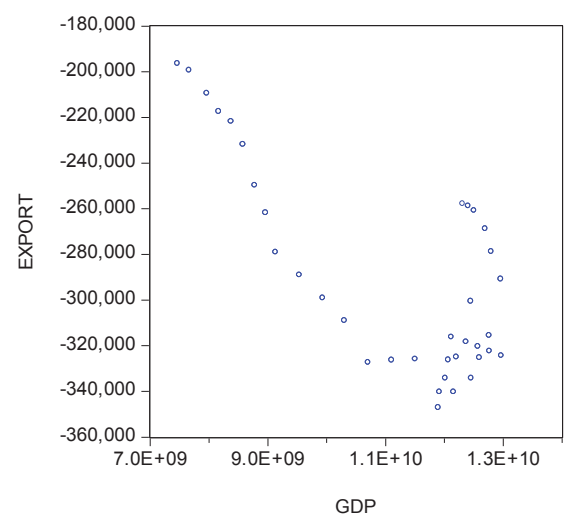

\section{GDP \& FDI (Scatter)}

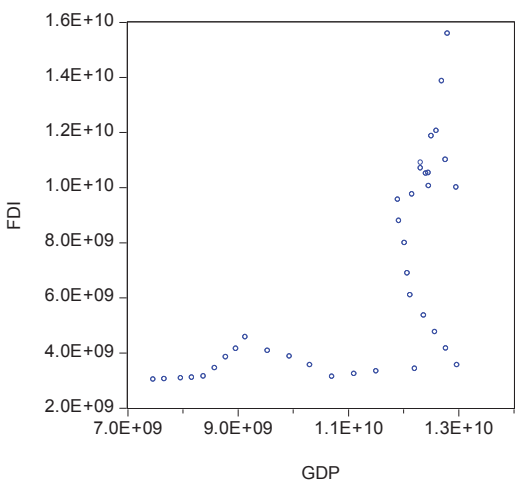




\section{GDP \& Remittances (Scatter)}

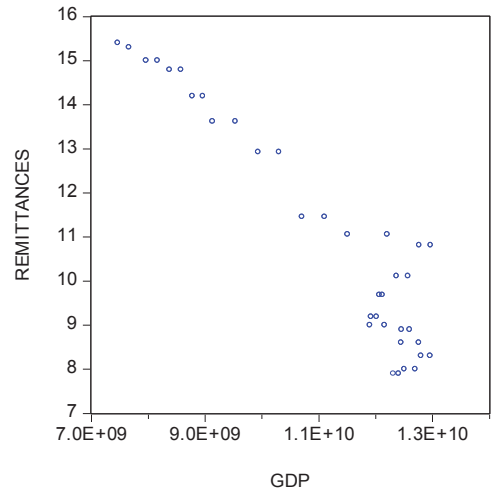

\section{GDP Histogram}

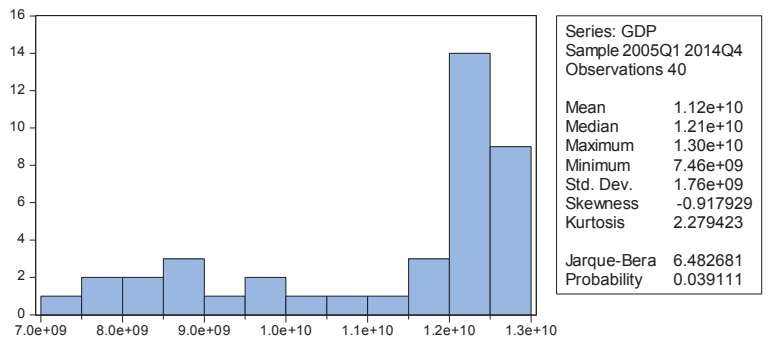

For the GDP the skewness is -0.917929 which is near to 0 and kurtosis is 2.279423 which is near to 3 meaning that the GDP has a normal distribution.

\section{FDI Histogram}

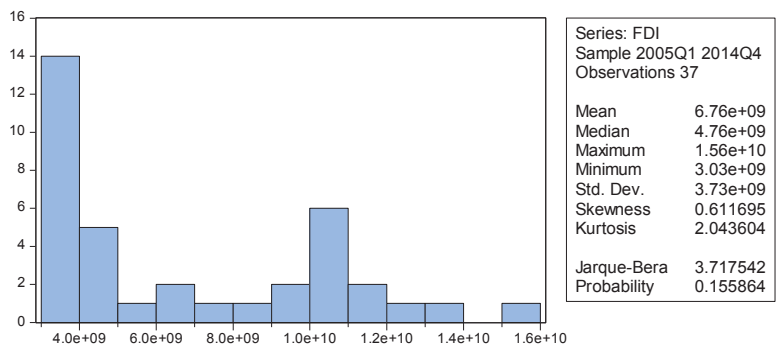

For the FDI the skewness is 0.611695 which is near to 0 and kurtosis is 2.043604 which is near to 3 meaning that the FDI has a normal distribution. 


\section{Export Histogram}

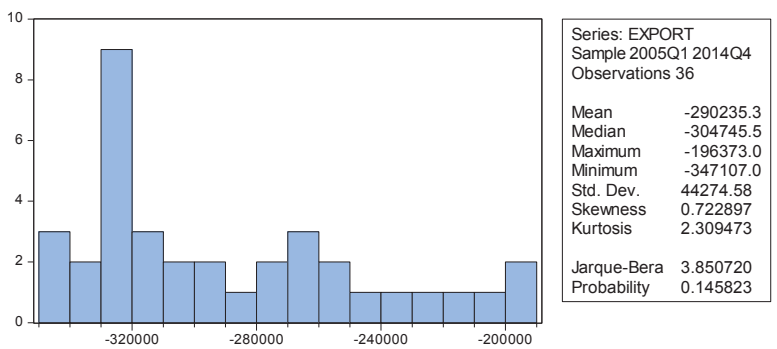

For the Export the skewness is 0.722897 which is near to 0 and kurtosis is 2.309473 which is near to 3 meaning that the Export has a normal distribution.

\section{Remittances Histogram}

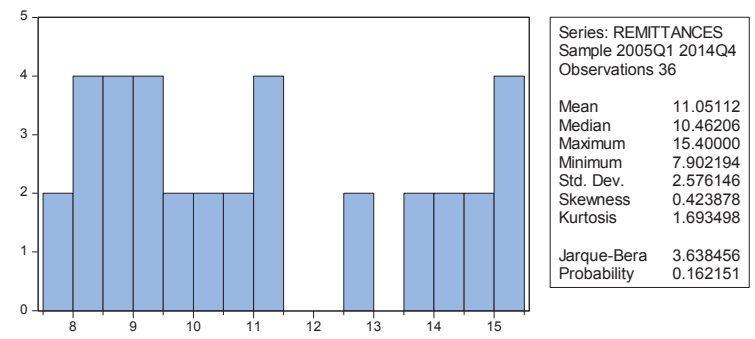

For the RMT the skewness is 0.423878 which is near to 0 and kurtosis is 1.692151 which is near to 3 meaning that the GDP has a normal distribution.

Table 1. Group Statistics

$\begin{array}{lcccc} & \text { GDP } & \text { FDI } & \text { EXPORT } & \text { REMITTANCES } \\ \text { Mean } & 1.11 \mathrm{E}+10 & 6.65 \mathrm{E}+09 & -290235.3 & 11.05112 \\ \text { Median } & 1.20 \mathrm{E}+10 & 4.67 \mathrm{E}+09 & -304745.5 & 10.46206 \\ \text { Maximum } & 1.30 \mathrm{E}+10 & 1.56 \mathrm{E}+10 & -196373.0 & 15.40000 \\ \text { Minimum } & 7.46 \mathrm{E}+09 & 3.03 \mathrm{E}+09 & -347107.0 & 7.902194 \\ \text { Std. Dev. } & 1.81 \mathrm{E}+09 & 3.72 \mathrm{E}+09 & 44274.58 & 2.576146 \\ \text { Skewness } & -0.753050 & 0.690814 & 0.722897 & 0.423878 \\ \text { Kurtosis } & 1.997789 & 2.171666 & 2.309473 & 1.693498 \\ \text { Jarque-Bera } & 4.909149 & 3.892549 & 3.850720 & 3.638456 \\ \text { Probability } & 0.085900 & 0.142805 & 0.145823 & 0.162151 \\ \text { Sum } & 3.99 \mathrm{E}+11 & 2.39 \mathrm{E}+11 & -10448469 & 397.8403 \\ \text { Sum Sq. Dev. } & 1.15 \mathrm{E}+20 & 4.84 \mathrm{E}+20 & 6.86 \mathrm{E}+10 & 232.2785 \\ \text { Observations } & 36 & 36 & 36 & 36\end{array}$


Table 2: Estimation Equation Output

Dependent Variable: GDP

Method: Least Squares

Date: 06/28/14 Time: 16:51

Sample (adjusted): 2005Q1 2013Q4

Included observations: 36 after adjustments

\begin{tabular}{lcccc}
\hline \hline \multicolumn{1}{c}{ Variable } & Coefficient & Std. Error & t-Statistic & Prob. \\
& & & & \\
\hline \hline C & $1.84 \mathrm{E}+10$ & $1.89 \mathrm{E}+09$ & 9.706550 & 0.0000 \\
FDI & -0.117662 & 0.046425 & -2.534467 & 0.0164 \\
EXPORT & -5871.523 & 2803.224 & -2.094561 & 0.0442 \\
REMITTANCES & $-7.43 \mathrm{E}+08$ & 82909810 & -8.961895 & 0.0000 \\
& & & & \\
\hline \hline R-squared & 0.944073 & Mean dependent var & $1.11 \mathrm{E}+10$ \\
Adjusted R-squared & 0.938829 & S.D. dependent var & $1.81 \mathrm{E}+09$ \\
S.E. of regression & $4.48 \mathrm{E}+08$ & Akaike info criterion & 42.78501 \\
Sum squared resid & $6.44 \mathrm{E}+18$ & Schwarz criterion & 42.96096 \\
Log likelihood & -766.1303 & Hannan-Quinn criter. & 42.84642 \\
F-statistic & 180.0569 & Durbin-Watson stat & 0.679575 \\
Prob(F-statistic) & 0.000000 & & \\
& & & \\
\hline \hline
\end{tabular}

Table 3. Augmented Dickey-Fuller Unit Root Test on GDP, FDI, RMT and Export

\begin{tabular}{l|cccc}
\multicolumn{1}{c}{ Variables } & 1\% level & $5 \%$ level & $10 \%$ level & Propability \\
\hline GDP & -3.615588 & -2.941145 & -2.609066 & 0.1631 \\
FDI & -3.632900 & -2.948404 & -2.612874 & 0.7990 \\
RMT & -3.639407 & -2.951125 & -2.614300 & 0.2529 \\
Export & -3.639407 & -2.951125 & -2.614300 & 0.1316 \\
\hline
\end{tabular}

Table 4. Johansen Cointegration Test

Unrestricted Cointegration Rank Test (Trace)

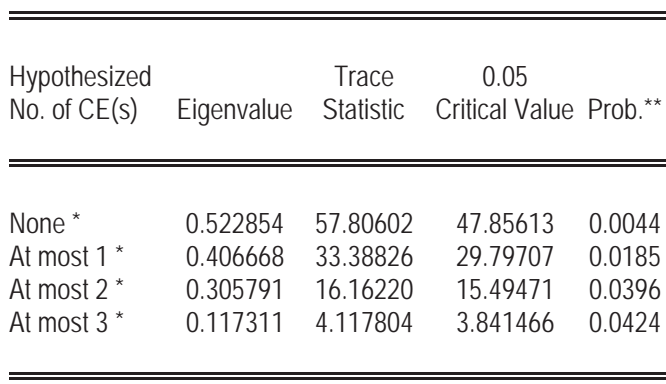

Trace test indicates 4 cointegrating eqn(s) at the 0.05 level

* denotes rejection of the hypothesis at the 0.05 level

**MacKinnon-Haug-Michelis (1999) p-values

Unrestricted Cointegration Rank Test (Maximum Eigenvalue)

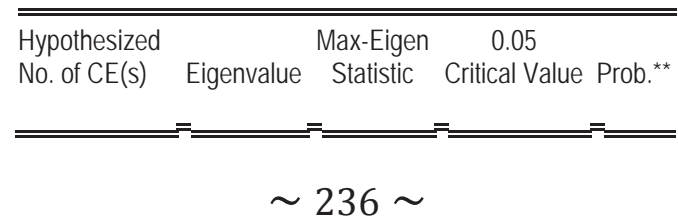




\begin{tabular}{lllll} 
None & 0.522854 & 24.41776 & 27.58434 & 0.1208 \\
At most 1 & 0.406668 & 17.22606 & 21.13162 & 0.1616 \\
At most 2 & 0.305791 & 12.04439 & 14.26460 & 0.1090 \\
At most 3 * & 0.117311 & 4.117804 & 3.841466 & 0.0424 \\
& & & & \\
\hline \hline
\end{tabular}

Max-eigenvalue test indicates no cointegration at the 0.05 level

* denotes rejection of the hypothesis at the 0.05 level

**MacKinnon-Haug-Michelis (1999) p-values

In Table 5, Trace test indicates 4 co-integrating equations at the 0.05 level where the Trace statistic is greater than $5 \%$ critical value while Max-Eigen value test indicates that there is no co-integration at 0.05 level because Max-Eigen statistic is lower than $5 \%$ critical value. In other words GDP and the other three variables: INF, RMT, and the FDI are cointegrated to each other but in the long run this co-integration is weak.

\section{Conclusions}

As stated on the above datas and conclsions from the equations, it is proved that GDP is correlated with the variables of RMT, FDI and INF. Albania has been suffering a tightening in budget and rising in public debt.

This study has attempted to contribute to the public debate on the current impact of the european crisis on Albania. The pace of the return of Albanian migrants is one of the worrying factors that need to be monitored carefully. Albania in the short term cannot increase its social security net or invest in its health system as it is significantly lowering public spending in order to maintain its public debt at less than 60\% of GDP.

The government must stop thinking in short term policies but rather attract foreign investments and make high profit investments.

\section{References}

"Economic Crisis in Europe: Causes, Consequences and Responses," Economic and Financial Affairs, European Union, 2009.

Calvo and Guillermo, "Servicing the Public Debt: The Role of Expectations," American Economic Review, Vol. 78, No. 4, 1998, pp. 647661

B. Eichengreen, R. Hausmann and U. Panizza, "The Pain of Original Sin", Other People'S Money: Debt Denomi-nation and Financial Instability in Emerging Market Economies, Chicago University Press, Chicago, 2005.

M. Dooley, "Can Output Losses Following International Financial Crises be Avoided?" National Bureau of Eco-nomic Research Working Paper, No. 7531, 2000.

D. Leigh, "Will it hurt? Macroeconomic Effects of Fiscal consolidation," International Monetary Fund, October 2010.

P. De Grauwe and W. Moesen, "Gains for All: A Pro-posal for a Common Eurobond," Intereconomics, May/ June, 2009.

Instat.gov.al

World Bank

Bank of Albania

The Economics of Money, Banking, and Financial Markets,7th ed., Columbia University, 2004.

Mundell, R.,(1963),"Inflation and real interest", The journal of Political Economy, 71 ,280-283.

www.Indexmundi.com

Custom of Albania

Ministry of Finance 